\title{
PERANAN HUKUM PIDANA PADA PENYELESAIAN SENGKETA PEMBATALAN SERTIFIKAT HAK ATAS TANAH OLEH KEPALA KANTOR WILAYAH BADAN PERTANAHAN NASIONAL
}

Oleh :

\author{
ELEONORA SINAY MONIUNG \\ KEYZHA NATAKHARISMA
}

\author{
Program Studi, Fakultas Hukum Universitas Mahendradatta \\ Jl. Ken Arok No. 12 , Peguyangan Denpasar Utara, Bali 80115. \\ (keyzha natakharisma@gmail.com)
}

\begin{abstract}
ABSTRAK. Pendaftaran tanah di Indonesia menggunakan sistem publikasi negatif. Dalam sistem publikasi negatif, negara hanya secara pasif menerima apa yang dinyatakan oleh pihak yang meminta pendaftaran.akibat yang timbul dari sistem ini setiap orang berhak melakukan gugatan terhadap sertifikat tanah tersebut untuk dibatalkan, kemdahan ini cenderung dimanfaatkan mafia tanah untuk melakukan pembatalan tanah berkerjasama dengan oknum pejabat BPN oleh karena itu dalam penelitian ini membahas sejauh mana hukum pidana mengatur perbuatan tersebut. Penelitian ini mempergunakan pendekatan yuridis normatif. Maksud dari istilah,"pendekatan/approach" adalah sesuatu hal atau (perbuatan atau usaha) mendekati atau mendekatka, Spesifikasi penelitian yang digunakan adalah metode deskriptif analitis yaitu menggambarkan mengenai peran hukum pidana dalam penyelesaian pembatalan tanah dengan penyalahgunaan kewenangan,Sumber-sumber penelitian dalam penelitian ini bahan-bahan hukum primer dan bahan-bahan hukum sekunder,Analisis data pada penelitian hukum normatif pada hakekatnya adalah kegiatan untuk mengadakan ssitematika terhadap bahan-bahan hukum tertulis. Pemberian sanksi terhadap pejabat BPN/Kepala BPN yang ikut terlibat dalam pembatalan tanah yang tidak sesuai prosedur dan bermain dapat diberikan sanksi pidana serta dengan pemberian sanksi pidana kepada mereka pejabat BPN yang bermain diharapkan dapat menekan jumlah pembatalan tanah yang illegal.
\end{abstract}

\section{KataKunci : Pembatalan Tanah, Pejabat BPN, HukumPidana}

ABSTRACT. Land registration in Indonesia uses a negative publication system. In a negative publication system, the state only passively accepts what is stated by the party requesting registration. As a result of this system, every person has the right to make a claim against the land certificate to be canceled, this land tends to be used by the land mafia to cancel the land in collaboration with an individual. BPN officials therefore in this study discuss the extent to which criminal law regulates these acts. This study uses a normative juridical approach. The purpose of the term, "approach / approach" is something or (action or effort) approaching or approaching, research specifications used are descriptive analytical methods that describe the role of criminal law in the completion of the annulment of land with abuse of authority, research sources in research these are primary legal materials and secondary legal materials. Data analysis on normative legal research is essentially an activity to conduct a mathematical study of written legal materials. Imposing sanctions against BPN officials / Head of BPN who are involved in the cancellation of land that is not in accordance with procedures and play can be given criminal sanctions as well as by providing criminal sanctions to those BPN officials who play are expected to reduce the number of illegal land cancellations.

Keywords: Land Cancellation, BPN Official, Criminal Law 
PENDAHULUAN

\section{A. Latar Belakang}

Indonesia merupakan negara hukum berdasarkan Pancasila dan Undang-undang Dasar Tahun 1945 (UUD 45) yang menjamin kepastian, ketertiban dan perlindungan hukum yang berintikan kebenaran dan keadilan. ${ }^{103}$ Ketertiban adalah tujuan pokok dan pertama dari segala hukum, dan ketertiban itu pula yang merupakan syarat fundamental bagi adanya suatu masyarakat yang teratur, ${ }^{104}$ maka hukum mempunyai kedudukan paling tinggi dalam pemerintahan dan hukum adalah perlindungan kepentingan manusia. ${ }^{105}$ Sebagai negara hukum, Indonesia memiliki kewajiban untuk mewujudkan kesejahteraan umum, maka setiap kegiatan disamping harus diorientasikan pada tujuan yang hendak dicapai juga harus menjadikan hukum yang berlaku sebagai aturan hukum kegiatan kenegaraan, pemerintahan dan kemasyarakatan. ${ }^{106}$

Menurut konsep negara kesejahteraan (welfare state),

${ }^{103}$ Supriadi, Etika dan Tanggungjawab Profesi Hukum di Indonesia, Sinar Grafika, Jakarta, 2008. hlm.29.

${ }^{104}$ Mochtar Kusumaatmadja, Fungsi dan Perkembangan Hukum Dalam Pembangunan Nasional, Binacipta, Bandung, 1986. hlm.2. pemerintah bertugas tidak hanya terbatas untuk melaksanakan undang-undang yang telah dibuat oleh lembaga legislatif, akan tetapi ada kewajiban menyelenggarakannya (bestuurszorg) atau mengupayakan kesejahteraan sosial dan pelayanan masyarakat. Untuk itu kepada pemerintah diberi wewenang untuk campur tangan (staatsbemoeienis) dalam segala jenis lapangan kehidupan masyarakat.

Undang-undang nomor 5 tahun 1960 tentang Peraturan Dasar PokokPokok Agraria (UUPA), merupakan penjabaran dari Pasal 33 ayat (3) UUD 45 yang mengatur kewenangan negara atas tanah sebagaimana dimaksud dalam Pasal 2 ayat (2) UUPA, yakni bahwa:

$$
\begin{aligned}
& \text { "Hak menguasai dari Negara } \\
& \text { termaksud dalam ayat (1) } \\
& \text { pasal ini memberi } \\
& \text { wewenang untuk: }
\end{aligned}
$$

a. Mengatur dan menyelenggarakan peruntukan, penggunaan, persediaan dan pemeliharaan bumi, air dan ruang angkasa tersebut;

105 Sudikno Mertokusumo, Mengenal Hukum Suatu Pengantar, Liberty, Yogyakarta, 2003. hlm.21.

106 Ridwan HR, Hukum Administrasi Negara, Raja Grafindo Persada, Jakarta, 2006. hlm.194-241. 
b. Menentukan dan mengatur hubunganhubungan hukum antara orang-orang dengan bumi, air dan ruang angkasa,

c. Menentukan dan mengatur hubunganhubungan hukum antara orang-orang dan perbuatan-perbuatan hukum yang mengenai bumi, air dan ruang angkasa."

Selain memberikan kewenangan kepada negara, salah satu tujuan UUPA adalah meletakkan dasar-dasar untuk memberikan kepastian hukum mengenai hak atas tanah (registration of title) bagi seluruh rakyat Indonesia, sebagaimana dimaksud dalam ketentuan Pasal 19 ayat (1) UUPA, yang berbunyi:107 "Untuk menjamin kepastian hukum oleh pemerintah diadakan pendaftaran tanah di seluruh wilayah Republik Indonesia menurut ketentuan-ketentuan yang diatur dengan peraturan pemerintah."

Mendasarkan pada ketentuan Pasal 19 ayat (1) UUPA, Pemerintah pada tanggal 18 Oktober 1997 telah menetapkan Peraturan Pemerintah nomor 24 tahun 1997 tentang Pendaftaran Tanah sebagai hukum

${ }^{107}$ Adrian Sutedi, Peradilan Hak Atas Tanah dan Pendaftarannya, Sinar Grafika, Jakarta, 2008. hlm.14. positif pendaftaran tanah di Indonesia. Tujuan pelaksanaan pendaftaran tanah sebagaimana di atur dalam Pasal 3 Peraturan Pemerintah nomor 24 tahun 1997, berbunyi:

a. Memberikan kepastian hukum dan perlindungan hukum kepada pemegang hak atas suatu bidang tanah,

b. Menyediakan informasi kepada pihak-pihak yang berkepentingan termasuk Pemerintah,

c. Terselenggaranya tertib administrasi pertanahan.

Peraturan Pemerintah ini merupakan bentuk pelaksanaan pendaftaran tanah dalam rangka recht kadaster yang bertujuan memberikan kepastian hukum dan perlindungan hukum kepada pemegang hak atas tanah dengan alat bukti yang dihasilkan pada akhir proses pendaftaran tanah tersebut berupa Buku Tanah dan Sertifikat Tanah yang terdiri atas Salinan Buku Tanah dan Surat Ukur.

Pendaftaran tanah di Indonesia menganut sistem stelsel negatif, apabila sertifikat tanah telah diterbitkan atas nama seseorang dan ada pihak lain yang 
dapat membuktikan sebagai pemilik yang lebih berhak melalui putusan lembaga peradilan maka sertifikat tanah tersebut dapat dibatalkan yang kemudian diberikan kepada pihak yang lebih berhak atau dengan kata lain dalam konsepsi UUPA sertifikat hanya merupakan tanda bukti yang kuat dan bukan merupakan tanda bukti yang mutlak. Hal ini dapat diartikan bahwa keterangan-keterangan yang tercantum didalamnya mempunyai kekuatan hukum dan harus diterima sebagai keterangan yang benar selama dan sepanjang tidak ada alat pembuktian yang membuktikan sebaliknya. ${ }^{108}$

Sebagai kelanjutan dari pemberian perlindungan hukum kepada pemegang sertifikat dinyatakan dalam ketentuan Pasal 32 Peraturan Pemerintah nomor 24 tahun 1997 yang menyatakan :

1. Sertifikat merupakan tanda bukti hak yang berlaku sebagai alat pembuktian yang kuat mengenai data fisik dan data yuridis yang termuat di dalamnya.

2. Dalam hal sudah diterbitkan sertifikat secara sah ........, maka pihak lain yang merasa mempunyai hak atas

108 Arie S. Hutagalung, Penerapan Lembaga Rechtverweking Untuk Mengatasi Kelemahan Sistem Publikasi Negatif Dalam tanah itu tidak dapat lagi menuntut pelaksanaan hak tersebut apabila dalam jangka waktu 5 tahun sejak diterbitkan sertifikat itu tidak mengajukan keberatan....."

Pendaftaran tanah semacam ini menggunakan sistem publikasi negatif. Dalam sistem publikasi negatif, negara hanya secara pasif menerima apa yang dinyatakan oleh pihak yang meminta pendaftaran. ${ }^{109}$ Oleh karena itu, sewaktu-waktu dapat digugat oleh orang atau badan hukum yang merasa lebih ber-hak atas tanah itu. Pihak yang memperoleh tanah dan orang yang sudah terdaftar tidak dijamin, walaupun dia memperoleh tanah itu dengan itikad baik.

Sertifikat hak atas tanah merupakan tindakan atau perbuatan hukum pemerintah yang lahir karena undang-undang dan bersifat konkret. Tindakan-tindakan atau perbuatan hukum pemerintah dalam penerbitan sertifikat hak atas tanah didasarkan tugas-tugas pokok dan fungsi dari Badan Pertanahan Nasional (BPN) yang dibentuk dalam rangka melaksanakan

Pendaftaran Tanah, Hukum dan Pembangunan Bulan Oktober-Desember, 2000. hal.328. ${ }^{109}$ Adrian Sutedi, Op., Cit.,hal.113. 
fungsi pelayanan publik dibidang pelayanan pertanahan sebagaimana dimaksud dalam Peraturan Presiden nomor 10 tahun 2006 tentang Badan Pertanahan Nasional.

\begin{abstract}
Sengketa tanah kerap terjadi karena status kepemilikan. Tidak sedikit sebidang tanah mempunyai status kepemilikan ganda. Artinya, ada dua pihak, baik itu individu maupun organisasi yang mengaku memiliki tanah tersebut. Masalah akan muncul jika status kepemilikan (sertifikat) di kemudian hari berpindah tangan, baik itu melalui jual beli maupun warisan ataupun hibah.
\end{abstract}

Ada kalanya, masalah tanah muncul karena ketidaktahuan dan ketidakpedulian si pemilik tanah terhadap status tanah yang dimilikinya. Maksudnya, si pemilik tidak mendaftarkan tanah kepada institusi yang berwenang, Kantor Pertanahan ataupun Badan Pertanahan Nasional. Padahal, sertifikasi tanah sangat penting dalam hal keabsahannya (legalitas) di mata hukum.Adanya sertifikat tanah, legalitasnya menjadi kuat dan sah. Si pemilik tanah juga tidak akan merasa khawatir pada harta (tanah) yang dimilikinya.
Pada saat ini dalam praktek banyak beredarnya sertifikat palsu, sertifikat asli tetapi palsu atau sertifikat ganda di masyarakat sehingga pemegang hak atas tanah perlu mencari informasi tentang kebenaran data fisik dan data yuridis yang tertera dalam sertifikat tersebut di Kantor Pertanahan setempat. Pada umumnya masalah baru muncul dan diketahui terjadi penerbitan sertifikat ganda, yaitu untuk sebidang tanah diterbitkan lebih dari satu sertifikat bahkan sampai tiga yang letak tanahnya saling tumpang tindih, ketika pemegang sertifikat yang bersangkutan akan melakukan suatu perbuatan hukum atas bidang tanah yang dimaksud.

Persoalan kompleks yang terjadi pada perkara pertanahan salah satunya yaitu banyaknya mafia serta spekulan tanah yang tidak henti-hentinya melakukan aksinya dengan menghalalkan berbagaicara untuk mendapatkan/ merebut tanah yang bukan miliknya termasuk bekerjasama dengan oknum pejabat BPN agar rencananya dapat berjalan dengan lancer.

\section{B. Identifikasi Masalah}

Berdasarkan uraian tersebut di atas, dalam penulisan penelitian ini, 
penulis mengidentifikasikan pokok permasalahannya sebagai berikut :

1. Apakah Sanksi Pidana Dapat Diberikan Terhadap Kepala Kantor Wilayah Badan Pertanahan Nasional Yang Melakukan Pembatalan Sertipikat Tanah.

2. Bagaiamanakah Peran Hukum Pidana Dalam Menyelesaikan Permasalahan Pembatalan Sertipikat Tanah Oleh Kepala Kantor Wilayah Badan Pertanahan Nasional.

\section{BAB II}

\section{METODE PENELITIAN}

Pendekatan yuridis normatif yang berkaitan dengan analisis konstruksi hukum, filsafat hukum dan hukum yang berlaku, terutama mengacu pada peraturan perundangundangan yakni KUHP dan Undang-Undang Pokok Agraria. Sebagaimana kaitan dengan bagaimana peranan hukum pidana dapat menjadikan suatu jalan terakhir apabila didalam suatu pembuatan atas sertifikat atas Hak Milik tanah dibatalkan oleh Kepala Kantor Wilayah Badan Pertanahan.

110Pusat Pembinaan dan Pengembangan Bahasa, Kamus Besar Bahasa Indonesia, Balai Pustaka, Jakarta, 1994, hlm. 234. 
(pasir, cadas, napal dan sebagainya).

Berdasarkan pengertian

etimologi di atas, dapat kita pahami bahwa tanah adalah permukaan bumi dengan segala kandungan atau bahan yang ada didalamnya.

Iman Sudiyat, tanah secara geologisagronomis, yaitu ${ }^{111}$ :

Tanah adalah lapisan lepas permukaan bumi yang paling atas yang dimanfaatkan untuk menanami tumbuhtumbuhan. Itulah sebabnya kemudian dikenal istilah tanah garapan, tanah pekarangan, tanah pertanian, tanah perkebunan. Sedangkan yang digunakan untuk mendirikan bangunan dinamakan tanah bangunan. Kedalaman lapisan bumi (tanah) adalah sedalam irisan bajak, lapisan pembentukan humus dan lapisan dalam. Secara yuridis dikatakan bahwa tanah dikualifikasi sebagai permukaan bumi.

Berdasarkan pendapat para ahli tersebut maka pengertian tanah adalah permukaan bumi (yuridis) yang menyimpan kekayaan untuk mencukupi kebutuhan hidup dan kehidupan manusia

${ }^{111}$ Iman Sudiyat, Beberapa Masalah Penguasaan Tanah di Berbagai Masyarakat Sedang Berkembang, Badan Pembinaan Hukum Nasional Departemen Kehakiman, Jakarta, 1982, hlm.11. perseorangan dan kelompok (ekonomi). Tanah sebagai tempat tinggal atau kediaman, tempat mereka mengembangkan kehidupan keluarga secara turun-temurun dan bersifat abadi.

Dalam Black's Law Dictionary disebutkan tanah diartikan dalam dua arti yaitu. $^{112}$

1. An immovable and indestructible three-dimensional area consisting of a portion of the earth's surface, the space above and below the surface and everything growing on or permanently affixed to it.

2. An estate or interest in real property.

Yang diterjemahkan bebas dalam artiannya:

1. Area tiga dimensi yang tidak dapat dipindahkan dan yang tidak dapat dihancurkan yang terdiri atas bagian di atas permukaan tanah, ruang diatasnya dan bagian yang berada di bawah permukaan tanah dan segala sesuatu yang

${ }^{112 H e n r y ~ C a m p b e l l ~ B l a c k, ~ B l a c k ' s ~ L a w ~}$ Dictionary, seventh edition, USA : West Publishing, Minnesota. 1999, hlm. 67. 
tumbuh diatasnya dan terikat secara permanen.

2. Sebuah perumahan atau keuntungan dari kepemilikan lahan dan bangunan

\subsection{Teori Kewenangan}

Wewenang merupakan bagian yang sangat penting dalam Hukum Tata Pemerintahan (Hukum Administrasi), karena pemerintah baru dapat menjalankan fungsinya atas dasar wewenang yang diperolehnya.Keabsahan tindakan pemerintahan diukur berdasarkan wewenang yang diatur dalam peraturan perundang-undangan.Suatu kewenangan harus didasarkan pada ketentuan hukum yang berlaku sehingga bersifat sah.Perihal kewenangan dapat dilihat dari Konstitusi Negara yang memberikan legitimasi kepada Badan Publik dan Lembaga Negara dalam menjalankan fungsinya. Wewenang adalah kemampuan bertindak yang diberikan oleh undang-undang yang

${ }^{113}$ SF. Marbun, Peradilan Administrasi Negara dan Upaya Administrasi di Indonesia, Liberty, Yogyakarta, 1997, hlm. 154.

${ }^{114}$ Indroharto, Usaha Memahami Undang-Undang tentang Peradilan Tata Usaha Negara, Pustaka Sinar Harapan, Jakarta, 1991, hlm. 68 . berlaku untuk melakukan hubungan dan perbuatan hukum ${ }^{113}$.

Kewenangan dalam arti yuridis adalah suatu kemampuan yang diberikan oleh Peraturan Perundang-undangan yang berlaku untuk menimbulkan akibat-akibat hukum ${ }^{114}$.ada 2 (dua) sumber untuk memperoleh wewenang yaitu atribusi dan delegasi. Namun dikatakan pula bahwa kadangkala mandat digunakan sebagai cara tersendiri dalam memperoleh wewenang ${ }^{115}$.

\section{F.A.M. Stroink dan J.G. Steenbeek}

berpendapat, yaitu:

Hanya ada dua cara organ memperoleh wewenang, yaitu atribusi dan delegasi. Atribusi berkenaan dengan penyerahan suatu wewenang baru, sedangkan delegasi menyangkut pelimpahan wewenang yang telah ada (oleh organ yang telah memperoleh wewenang secara atributif) kepada organ lain ; jadi delegasi secara logis selalu didahului oleh atribusi. Mandat tidak mengakibatkan perubahan apapun,

\footnotetext{
115 Philipus M . Hadjon, dkk, Pengantar Hukum Administrasi Negara Indonesia (Introduction to the Indonesia Administrative Law), Cet. I, Gajah Mada University Press, Yogyakarta, 1993, hlm.128129.
} 
sebab yang ada hanyalah hubungan internal, seperti menteri dengan pegawai untuk mengambil keputusan tertentu atas nama menteri, sementara secara yuridis wewenang dan tanggung jawab tetap berada pada organ kementerian. Pegawai memutuskan secarateknis, sedangkan menteri secara yuridis. ${ }^{116}$

Wewenang yang diperoleh dari hak menguasai Negara di tingkat pusat ada di tangan pemerintah. Wewenang tersebut sebagian dapat dilimpahkan kepada pejabat daerah sebagai wakil pemerintah pusat di daerahnya masingmasing guna membantu kelancaran pembangunan daerah. ${ }^{117}$ Berdasarkan kewenangan yang diatur dalam Undang Undang Pokok Agraria No 5 Tahun 1960 selanjutnya disebut UUPA maka kewenangan menetapkan kebijakan pertanahan dilaksanakan oleh pemerintah Pusat dan pelaksanaan kebijakan itu sebagian diserahkan kepada pemerintah daerah berdasarkan kewenangan delegasi. Kewenangan sangat relevan sebagai landasan teori dalam pembahasan ini, karena

${ }^{116}$ F.A.M. Stroink dan J.G. Steenbeek dikutip dari H.R. Ridwan, cara perolehan wewenang pada hakikatnya melalui cara atribusi dan delegasi, Hukum Administrasi Negara, UII Press, Yogyakarta, 2002, hlm .46. keabsahan tindakan pemerintah dalam penertiban dan pendayagunaan tanah terlantar diukur berdasarkan wewenang yang diatur dalam peraturan perundangundangan yang berlaku.

\subsection{Asas-Asas Umum Pemerintahan} Yang Baik.

Asas-Asas Umum Pemerintahan Yang Baik merupakan norma bagi perbuatan-perbuatan Administrasi Negara atau pemerintah, disamping norma-norma di dalam hukum tertulis dan tidak tertulis. Asas-Asas Umum Pemerintahan Yang Baik (selanjutnya disebut AUPB) harus dipandang sebagai norma-norma hukum tidak tertulis yang senantiasa harus diperhatikan dan ditaati oleh pemerintah dalam mengambil tindakan dalam menjalankan pemerintahan.

$$
\begin{aligned}
& \text { Adapun AUPB terdapat } \\
& \text { dikatagorikan kedalam } 13 \\
& \text { (tigabelas) asas, yaitu }{ }^{118} \text { : } \\
& \text { 1. Asas Kepastian Hukum } \\
& \text { (principle of legal security); }
\end{aligned}
$$

\footnotetext{
117 Imam Sutiknjo, Politik Agraria Nasional, Gadjah Mada University Press, Yogyakarta, 1994, hlm.56-57.

${ }^{118}$ C.S.T. Kansil dan Cristine S.T.

Kansil, Pengantar Ilmu Hukum Indonesia, Cetakan Pertama, Rineka Cipta, Jakarta 2011., hlm. 365.
} 
2. Asas Keseimbangan Hukum (principle of proportionality);

3. Asas Bertindak Cermat (principle of carefulness);

4. Asas Motivasi Untuk Setiap Keputusan Pangreh (principle of motivation);

5. Asas Jangan

Mencampuradukan

Kewenangan (principle of non misuse of competence);

6. Asas Kesamaan Dalam Mengambil Keputusan (principle of equality);

7. Asas Permainan Yang Layak (principle of fair play);

8. Asas Keadilan atau Kewajaran (principle of reasonable of prohibition of arbitrariness);

9. Asas Menanggapi Pengharapan Yang Wajar ( Principle of meeting raised expectation );

10. Asas Meniadakan Akibat Suatu Keputusan Yang Batal (principle of undoing the consequences of unneled decision );

11. Asas Perlindungan atas Pandangan (Cara) Hidup

Pribadi (principle of protetcting the personal way of life );

12. Asas kebijaksanaan (principle of sapiently);

13. Asas Penyelenggaraan Kepentingan Umum (principle of public service).

Tindakan pemerintah dalam penertiban dan pendayagunaan tanah terlantarharus memperhatikan asas-asas umum pemerintahan yang baik sehingga tindakan pemerintah dalam penertiban dan pendayagunaan tanah terlantar sesuai dengan peraturan perundangundangan yang berlaku dan tidak merugikan masyarakat atau pihak-pihak yang terkena tindakan tersebut.

\subsection{Hukum Pidana}

$$
\begin{aligned}
& \text { Indonesia adalah Negara } \\
& \text { yang berdasarkan atas Hukum } \\
& \text { (Penjelasan Umum UUD 1945) }
\end{aligned}
$$
tidak berdasarkan kekuasaan negara semata-mata, sehingga hukumlah yang mempunyai arti yang terutama dalam segala segi-segi kehidupan masyarakat, maka pemberian titik berat fungsi negara pada definisi hukum pidana perlu dihindarkan. Untuk menentukan isi pokok dari definisi hukum pidana, kiranya dapat disimpulkan bahwa hukum pidana adalah: Hukum positif; Hukum yang menentukan tentang perbuatan pidana dan menentukan tentang kesalahan bagi si pelanggarannya (substansi hukum pidana); Hukum yang menentukan tentang pelaksanaan substansi hukum pidana (hukum acara pidana). 
Isi pokok definisi hukum pidana tersebut dalam nomor 2 dan 3 diatas yang memuat ketentuan substansi hukum pidana dan hukum acara pidana, meskipun di dalam perkembangannya dapat dipisahkan masing-masing menjadi lapangan hukum tersendiri, akan tetapi banyak permasalahannya yang tidak dapat dipisahkan dengan jelas satusama lain.

\section{BAB IV}

\section{PEMBAHASAN}

\section{A. Pemberian Sanksi Pidana Terhadap Kepala Kantor Wilayah Badan Pertanahan Nasional Yang Melakukan Pembatalan Sertipikat Tanah.}

Indonesia merupakan negara hukum berdasarkan Pancasila dan Undang-undang Dasar Tahun 1945 (UUD 45) yang menjamin kepastian, ketertiban dan perlindungan hukum yang berintikan kebenaran dan keadilan. Ketertiban adalah tujuan pokok dan pertama dari segala hukum, dan ketertiban itu pula yang merupakan syarat fundamental bagi adanya suatu masyarakat yang teratur, maka hukum mempunyai kedudukan paling tinggi dalam pemerintahan dan hukum adalah perlindungan kepentingan manusia.

Konsep negara hukum selanjutnya yang masih berpengaruh dan ikut mewarnai negara-negara modern sampai saat ini adalah konsep Friedrich Julius Stahl yang mengajarkan, bahwa tugas negara tidak sekedar penjaga malam, tetapi berkembang lebih luas dan aktif campur tangan dalam bidang ekonomi, sosial dan budaya. Konsep seperti ini dikenal dengan istilah Welvaarstaat atau negara kesejahteraan. ${ }^{119}$ Konsep Stahl tentang negara hukum tersebut ditandai oleh empat unsur pokok, yaitu :

1. Pengakuan dan perlindungan terhadap hak-hak dasar manusia;

2. Negara didasarkan pada teori trias politika (pemisahan kekuasaan);

3. pemerintahan diselenggarakan berdasarkan aturan hukum atau undang-undang (wetmatig bestuur);

4. Adanya peradilan administrasi negara yang bertugas menangani kasus melanggar hukum oleh pemerintah. ${ }^{120}$

${ }^{120}$ Ibid, hlm. 135 
Sebagaimana pandangan

Stahl diatas naka Indonesia sebagai Negara hukum harus menyelenggarakan pemerintahan didasarkan atas aturan hukum perundang-undanganm berbicara proses pembatalan tanah yang dilakukan oleh bpn tidak bias terlepas dari proses pendaftaran dan sisitem pendaftaran tanah di Indonesia.

Dalam ketentuan Pasal 19 ayat (1) UUPA, yang berbunyi: ${ }^{121}$ “Untuk menjamin kepastian hukum oleh pemerintah diadakan pendaftaran tanah di seluruh wilayah Republik Indonesia menurut ketentuan-ketentuan yang diatur dengan peraturan pemerintah."

Selanjutnya pada ketentuan Pasal 19 ayat (1) UUPA, Pemerintah pada tanggal 18 Oktober 1997 telah menetapkan Peraturan Pemerintah nomor 24 tahun 1997 tentang Pendaftaran Tanah sebagai hukum positif pendaftaran tanah di Indonesia. Tujuan pelaksanaan pendaftaran tanah sebagaimana di atur dalam Pasal 3 Peraturan Pemerintah nomor 24 tahun 1997, berbunyi:

a. Memberikan

kepastian hukum dan

perlindungan hukum

kepada pemegang

hak atas suatu bidang

tanah,

b. Menyediakan

informasi kepada

pihak-pihak yang

berkepentingan

termasuk

Pemerintah,

c. Terselenggaranya

tertib administrasi

pertanahan.

Peraturan Pemerintah ini merupakan bentuk pelaksanaan pendaftaran tanah dalam rangka recht kadaster yang bertujuan memberikan kepastian hukum dan perlindungan hukum kepada pemegang hak atas tanah dengan alat bukti yang dihasilkan pada akhir proses pendaftaran tanah tersebut berupa Buku Tanah dan Sertifikat Tanah yang terdiri atas Salinan Buku Tanah dan Surat Ukur.

${ }^{121}$ Adrian Sutedi, Op.cit hlm.14. 
Pendaftaran tanah di

Indonesia menganut sistem stelsel negatif, apabila sertifikat tanah telah diterbitkan atas nama seseorang dan ada pihak lain yang dapat membuktikan sebagai pemilik yang lebih berhak melalui putusan lembaga peradilan maka sertifikat tanah tersebut dapat dibatalkan yang kemudian diberikan kepada pihak yang lebih ber-hak atau dengan kata lain dalam konsepsi UUPA sertifikat hanya merupakan tanda bukti yang kuat dan bukan merupakan tanda bukti yang mutlak. Hal ini dapat diartikan bahwa keterangan-keterangan yang tercantum didalamnya mempunyai kekuatan hukum dan harus diterima sebagai keterangan yang benar selama dan sepanjang tidak ada alat pembuktian yang membuktikan sebaliknya. ${ }^{122}$

Jika dikaji pada pemberian sanksi pidana dapatlah diberikan apabila Kepala Kantor Wilayah Badan Pertanahan Nasional dinilai kurang komperasif secara hukum pidana dengan sepihak melakukan

${ }^{122}$ Arie S. Hutagalung, Penerapan Lembaga Rechtverweking Untuk Mengatasi Kelemahan Sistem Publikasi Negatif Dalam pembatalan sertfikat atas Hak Milik itu dimana telah memang dapat dibuktikan kebenaran seseorang itu telah memilikinya maksudnya pembatalan tanpa adanya putusan ikrar dari pengadilan bahwa sertifikat Hak Milik telah memenuhi unsur pemalsuan atau tidak sah menurut peraturan perundanganundangan.

B. Peran Hukum Pidana Dalam Menyelesaikan Permasalahan Pembatalan Sertipikat Tanah Oleh Kepala Kantor Wilayah Badan Pertanahan Nasional.

Kepastian hukum di dalam Pasal 1 KUHP mengandung asas Asseln von Feuerbach atau nullum delictum nulla poena sine praevia lege poenali. Asas ini terkonkretisasi di dalam rumusan: "Tiada suatu perbuatan dapat dipidana kecuali atas kekuatan aturan pidana dalam peraturan perundang-undangan yang telah ada, sebelum perbuatan dilakukan". Hal itu berarti kepastian hukum mengharuskan adanya suatu norma pidana Bulan Oktober-Desember, 2000. hal.328. 
tertentu, norma itu harus berdasarkan peraturan perundangundangan dan bersifat non retroaktif. Kepastian hukum di dalam Pasal 1 KUHP ini disebut dengan asas legalitas.

Konsep tentang asas legalitas atau kepastian hukum juga dikemukakan oleh L. J. van Apeldoorn di dalam bukunya Inleiding tot de studie van het Nederlandse Recht. Apeldorrn sebagaimana dikutip Ermansah Djaja (2008: 37), mengatakan bahwa kepastian hukum itu memiliki dua sisi yakni adanya hukum yang pasti bagi suatu peristiwa yang konkret dan adanya perlindungan terhadap kesewenang-wenangan. Fuller (1971) sebagaimana dikutip oleh Ali memberikan makna yang lebih luas tentang kepastian hukum. Fuller menjabarkan pendapatnya tentang kepastian hukum, dengan menyatakan:

Kepastian hukum selalu berkaitan dengan hal-hal seperti: a.) adanya sistem hukum yang terdiri dari peraturan-peraturan, bukan berdasarkan putusan sesaat untuk hal-hal tertentu; b.) peraturan tersebut diumumkan kepada publik; c.) peraturan tersebut tidak berlaku surut; d.) dibuat dalam rumusan yang dimengerti oleh umum; e.) tidak boleh ada peraturan yang saling bertentangan; f.) tidak boleh menuntut suatu tindakan yang melebihi apa yang dapat dilakukan; g.) tidak boleh sering diubah-ubah; dan h.) harus ada kesesuaian antara peraturan dan pelaksanaan seharihari.

Peranan hukum pidana selain memberikan suatu bentuk kepastian hukum juga dapat memberikan suatu tindakan preventif (pencegahan) dimana kemudian hari nanti dapat menekan bentuk dari pemalsuan atas pendaftaran atau penerbitan suatu sertifikat hak milik sehingga tidak lagi menimbulkan dapat menimbulkan sengketa yang merugikan warga negara yang notaben nya telah dilindungi segala hak nya oleh Negara.

\section{BAB IV}

\section{KESIMPULAN}

1. Bahwa Sanksi Pidana dapat diberikan atau dikenakan kepada KANWIL Badan Pertanahan 
Nasional (BPN) yang melakukan

pembatalan sertifikat tanah tanpa alasan yang dikeluarkan oleh hakim. Misalnya pembatalan sertifikat tersebut mengandung unsur pidana pemalsuan surat. Dalam hal ini adalah segala surat, baik yang ditulis dengan tangan, dicetak,maupun ditulis memakai mesin tik, dan lainlainnya. Yang dapat menimbulkan sesuatu hak, Dapat menerbitkan suatu perjanjian, Dapat menerbitkan suatu hutang atau surat yang digunakan sebagai keterangan bagi suatu perbuatan atau peristiwa. Bentuk-bentuk pemalsuan surat yang dilakukan dengan cara ; membuat surat palsu, membuat isinya bukan semestiya (tidak benar), memalsu surat mengubah surat dengan sedemikan rupa sehingga isinya menjadi lain dari isi yang asli, caranya bermacam-macam, tidak senantiasa surat itu diganti dengan yang lain, dapat pula dengan cara mengurangkan, menambah atau merubah sesuatu dari surat itu. Lebih jauh dari itu bahkan dalam keadaan yang memerlukan syarat hukum untuk dibatalkan bila ternyata Sanksi Administrasi dan Sanksi Ganti Rugi dipandang belum efektif. Maka sudah saatnya kepada oknum KANWIL yang membatalkan sertifikat, dengan pertimbangan yang komprehensif semestinya dapat dikenakan sanksi pidana Denda.

2. Bahwa Sanksi Hukum Pidana memiliki peran yang signifikan untuk ikut serta mengantisipasi perbuatan-perbuatan melawan hukum berkenaan dengan masalah pembatalan sertifikat, yakni . Bukan saja berperan sebagai preventif (pencegahan) terhadap gangguan yang bisa mengancam pribadi atau kelompok. Akan tetapi sudah saatnya berperan Represif (penindakan). Setidak - tidaknya pengenaan pidana denda harus akumulatif atau kombinatif dengan sanksi ganti rugi. Hal ini penting mengingat masalah tanah dan sengketa tanah, sudah menjadi persoalan Hukum yang serius dan multidimensi. Karena itu antisipasi hukum perlu dilakukan terintegrasi. 
DAFTAR BACAAN

\section{Buku:}

Adrian Sutedi, Peradilan Hak Atas Tanah dan Pendaftarannya, Sinar Grafika, Jakarta, 2008.

Arie S. Hutagalung, Penerapan Lembaga Rechtverweking Untuk Mengatasi Kelemahan Sistem Publikasi Negatif Dalam Pendaftaran Tanah, Hukum dan Pembangunan Bulan Oktober-Desember, 2000.

C.S.T. Kansil dan Cristine S.T. Kansil, Pengantar Ilmu Hukum Indonesia, Cetakan Pertama, Rineka Cipta, Jakarta 2011.

F.A.M. Stroink dan J.G. Steenbeek dikutip dari H.R. Ridwan, cara perolehan wewenang pada hakikatnya melalui cara atribusi dan delegasi, Hukum Administrasi Negara, UII Press, Yogyakarta, 2002

Henry Campbell Black, Black's Law Dictionary, seventh edition, USA : West Publishing, Minnesota. 1999

Iman Sudiyat, Beberapa Masalah Penguasaan Tanah di Berbagai Masyarakat Sedang Berkembang, Badan Pembinaan Hukum Nasional Departemen Kehakiman, Jakarta, 1982

Imam Sutiknjo, Politik Agraria Nasional, Gadjah Mada University Press, Yogyakarta, 1994,

Indroharto, Usaha Memahami Undang-Undang tentang Peradilan Tata Usaha Negara, Pustaka Sinar Harapan, Jakarta, 1991

Mochtar Kusumaatmadja, Fungsi dan Perkembangan Hukum Dalam
Pembangunan Nasional, Binacipta, Bandung, 1986.

Philipus M . Hadjon, dkk, Pengantar Hukum Administrasi Negara Indonesia (Introduction to the Indonesia Administrative Law), Cet. I, Gajah Mada University Press, Yogyakarta, 1993

Pusat Pembinaan dan Pengembangan Bahasa, Kamus Besar Bahasa Indonesia, Balai Pustaka, Jakarta, 1994

Ridwan HR, Hukum Administrasi Negara, Raja Grafindo Persada, Jakarta, 2006.

Supriadi, Etika dan Tanggungjawab Profesi Hukum di Indonesia, Sinar Grafika, Jakarta, 2008.

Sudikno Mertokusumo, Mengenal Hukum Suatu Pengantar, Liberty, Yogyakarta, 2003.

SF. Marbun, Peradilan Administrasi Negara dan Upaya Administrasi di Indonesia, Liberty, Yogyakarta, 1997

\section{PeraturanPerundang-Undangan:}

Undang-Undang Dasar Republik Indonesia Tahun 1945 berikut amandemennya.

Undang-undang Nomor 8 tahun 1981 tentang Hukum Acar aPidana jo. Kitab Undang-undang Hukum Acara Pidana;

Peraturan Pemerintah Nomor 27 tahun 1983 tentang Pelaksanaan Kitab Undang-undang Hukum Acara Pidana 